\title{
Kajian Azaz Manfaat Jembatan Penyeberangan Orang (JPO) di Jalan Sultan Thaha Kota Jambi
}

\author{
Fakhrul Rozi Yamali
}

fakhrul_65@yahoo.co.id

\begin{abstract}
Abstrak
Fasilitas pejalan kaki sering terabaikan. Padahal pejalan kaki termasuk unsur arus lalu lintas yang perlu mendapat perhatian, khususnya di daerah perkotaan yang padat akan kendaraan. Tujuan dari penelitian ini adalah untuk mengetahui azaz manfaat dari Jembatan Penyeberangan Orang (JPO) di jalan Sultan Thaha dekat Mall WTC Kota Jambi. Penelitian yang dilakukan yakni melakukan survey pengguna JPO pada jam sibuk dan hari sibuk dan membandingkan lalu lintas di area penelitian. Hasil penelitian menilai kesesuaian fasilitas penyeberangan dengan persyaratan yang ada dan untuk merekomendasikan fasilitas yang sesuai dapat dihitung dari volume penyeberang jalan $(\mathrm{P})$ dan volume kendaraan tertinggi $(\mathrm{V})$ pada jam puncak yaitu $\mathrm{P}=325$ pejalan kaki/jam, $\mathrm{V}=2610,75 \mathrm{kend} . / \mathrm{jam}$. Berdasarkan rekomendasi pemilihan fasilitas penyeberangan, dapat ditarik kesimpulan fasilitas yang direkomendasikan adalah fasilitas penyeberangan Zebra Cross (ZC) dan sangat belum layak menggunakan JPO. Dari data persentase pertumbuhan penduduk di dapat perkiraan jumlah penyeberang yang akan menyeberang di jembatan baru akan mencapai Derajat Kejenuhan (DS) pada 8 tahun 3 bulan kedepan. Jumlah penyeberang jalan yang maksimum pada saat sekarang yaitu 564 orang/jam, dari data tersebut maka di dapat jumlah penyeberang pada tahun 2024 yaitu 1786 orang/jam.
\end{abstract}

Kata Kunci : JPO, penyeberang jalan, kepadatan lalulintas

\begin{abstract}
Pedestrian facilities are often overlooked. Whereas pedestrians include elements of traffic flow that need attention, especially in dense urban areas will be vehicles. The purpose of this research is to know the benefits of the Pedestrian Overpass (JPO) in Jalan Sultan Thaha near WTC Mall of Jambi City. The research conducted is to survey JPO users during peak hours and busy days and compare to the traffic in the research area. The results of the study assessed the suitability of the ferry facilities to the existing requirements and to recommend appropriate facilities can be calculated from the highest crossing volume $(P)$ and vehicle volume $(V)$ at peak hours ie $P=325$ pedestrians /hour, $V=2610.75$ vehicles./hour. Based on the recommendation of choosing a road crossing facility, it can be concluded that the recommended facilities are Zebra Cross (ZC) crossing facilities and it is not feasible to use JPO. From the percentage data of population growth in the estimation of the number of people who will use pedestrian overpass, it will work at 8 years 3 months ahead.
\end{abstract}

Keyword : Pedestrian Overpass, Crossers, traffic density

\section{PENDAHULUAN}

Tumbuh kembangnya suatu kota akan menimbulkan peningkatan aktivitas masyarakat dan permintaan akan jasa transportasi semakin meningkat sejalan dengan semakin tingginya arus lalu lintas di suatu perkotaan. Peningkatan lalulintas baik kendaraan maupun pejalan kaki pada suatu daerah sangat dipengaruhi 
oleh pertumbuhan ekonomi disekitarnya dan pertanda maju nya suatu daerah dengan maju pembangunan. Semakin maju dan berkembang suatu daerah akan semakin padat pula lalulintas kendaraan dan pejalan kaki pada daerah tersebut. Seiring peningkatan lalu lintas kendaraan dan pejalan kaki, akan terjadi konflik yang besar di antara keduanya yakni kebutuhan penggunaan jalan bagi kendaraan untuk melintas dan pejalan kaki untuk berlalu lalang atau menyeberangi ruas jalan tersebut. Masalah antara kendaraan dan pejalan kaki yang sudah sering terjadi adalah timbulnya kemacetan dan kecelakaan yang tidak bisa terelakkan yang berimbas menelan korban yang tidak sedikit.

Pembangunan infrastruktur merupakan salah satu pilar pendorong dalam peningkatan daya saing Indonesia dan memiliki multiplier effect yang signifikan bagi perekonomian masyarakat setiap daerah di Indonesia tak terkecuali di Provinsi Jambi. Pertumbuhan sektor jasa konstruksi mengalami peningkatan dengan meningkatnya sektor penopang pertumbuhan ekonomi, FR Yamali, 2017. Hal tersebut berbanding terbalik karena fasilitas pejalan kaki sering terabaikan sedangkan pejalan kaki termasuk unsur arus lalu lintas yang perlu mendapat perhatian, khususnya di daerah perkotaan yang padat akan kendaraan. Jumlah konflik antara pejalan kaki dan kendaraan dapat diatur dengan menyediakan fasilitas penunjang seperti zebra cross, pelican (pedestrian light control), penyediaan rambu dan sinyal untuk menyeberang jalan dan jembatan penyeberangan. Fasilitas penyeberangan adalah satu hal yang dapat dilakukan dengan berusaha memisahkan pejalan kaki dengan kendaraan agar tidak menimbulkan konflik antara pejalan kaki dengan pengendara. Jembatan penyeberangan merupakan merupakan pilihan yang nyaman sebagai fasilitas yang diperuntukkan untuk pejalan kaki sehingga ada kenyamanan dan untuk memudahkan para pejalan kaki menyeberang dijalan raya. Fenomena prilaku pejalan kaki di kota khususnya di Kota Jambi dalam hal penggunaan jembatan penyeberangan jalan umumnya belum menunjukkan pemanfaatan jembatan penyeberangan jalan secara optimal. Dari penjelasan di atas penulis mencoba merangkum permasalahan yang sering terjadi diantaranya :

1. Masyarakat lebih banyak yang menyeberang di ruas jalan dibandingkan dengan yang menyeberang di jembatan penyeberangan.

2. Kondisi jembatan penyeberangan pada saat ini tidak menjamin keamanan, kenyamanan dan keselamaatan bagi pengguna jembatan.

Tingkat pemanfaatan jembatan penyeberangan orang di jalan Sultan Thaha Kota Jambi yang berada di pusat perbelanjaan masih belum secara optimal dimanfaatkan masyarakat, sehingga penulis berkeinginan melakukan penelitian terkait hal ini dengan azaz manfaat pada JPO yang ada dengan: 1). Menganalisis tingkat pemanfaatan JPO, 2). Menganalisis volume lalu lintas saat ini untuk mendapatkan fasilitas penyeberangan orang pada ruas jalan tersebut, 3). Menghitung tingkat kepadatan (DS) lalu lintas, 4). Menghitung pada tahun berapakah Jembatan Penyeberangan Orang (JPO) di Jln. Sultan Thaha seharusnya di bangun atau termanfaatkan secara maksimal.

\section{TINJAUAN PUSTAKA}

\section{Pengertian Pejalan Kaki}

Pejalan kaki adalah orang yang melakukan aktifitas berjalan kaki dan merupakan salah satu unsur pengguna jalan. Pejalan kaki harus berjalan pada bagian jalan yang di peruntukkan bagi pejalan kaki, atau pada bagian pejalan kaki, 
atau pada bagian jalan yang paling kiri apabila tidak terdapat bagian jalan yang di peruntuhkan bagi pejalan kaki (Permenhub,1993).

\section{Ketentuan umum jalur pejalan kaki}

Jalur pejalan kaki adalah bagian paling penting dari fasilitas pejalan kaki, karena masyarakat di kota-kota besar mulai memanfaatkan fasilitas pejalan kaki di lingkungan sekitar, ada beberapa kriteria bentuk jalan untuk pejalan kaki yaitu sebagai berikut : 1). Trotoar, 2). Zebra cross, 3). Pelican cross atau zebra cross yang dilengkapi dengan lampu pengatur bagi penyeberang jalan dan kendaraan. 4). Jembatan penyeberangan, 5). Terowongan, 6). Non Trotoar

\section{Jembatan Penyeberangan Orang}

Jembatan Penyeberangan Orang (JPO) sebagai alat penyeberangan merupakan salah satu kebutuhan manusia dalam menyeberang jalur lalu lintas karena akhir-akhir ini banyak terjadi kecelakaan yang menimpa para penyeberang jalan. Hal ini disebabkan alur penyeberang jalan dan pengendara kendaraan menjadi satu serta tidak terpisah secara fisik. Meski telah ada fasilitas zebra cross, tetapi alur penyeberang jalan dan pengendara kendaraan tetap tidak terpisah secara fisik sehingga masih ada kemungkinan terjadinya kecelakaan. Jembatan Penyeberangan Orang (JPO) adalah jembatan yang letaknya bersilangan dengan jalan raya atau jalur kereta api, letaknya berada di atas kedua objek tersebut, dan hanya diperuntukkan bagi pejalan kaki yang melintas (menyeberang) jalan raya atau jalur kereta api. Jembatan Penyeberangan Orang juga dapat diartikan sebagai fasilitas pejalan kaki untuk menyeberang jalan yang ramai dan lebar, menyeberang jalan tol, atau jalur kereta api dengan menggunakan jembatan tersebut, sehingga alur sirkulasi orang dan lalu lintas kendaraan dipisah secara fisik dan kemungkinan terjadi kecelakaan dapat dikurangi. Jembatan penyeberangan juga digunakan untuk menuju tempat pemberhentian halte angkot. Karena posisinya yang lebih tinggi dari tanah, untuk memberikan akses kepada penderita cacat yang menggunakan kursi roda, di dekat tangga jembatan terdapat ramp dengan kelandaian tertentu. Langkah lain yang juga dilakukan untuk memberikan kemudahan akses bagi penderita cacat adalah dengan menggunakan tangga berjalan ataupun dengan menggunakan lift, sehingga mereka dapat dengan dengan mudah menggunakan fasilitas meskipun cacat.

\section{Kriteria Jembatan Penyeberangan Orang}

1. Kriteria Jalur Pejalan Kaki

2. Kriteria jembatan penyeberangan orang yang dibutuhkan

Menurut Pedoman Perencanaan Jalur Pejalan Kaki pada Jalan Umum (1999), JPO dipasang dengan ketentuan dari berbagai aspek yang dijabarkan sebagai berikut : a). Jalur Pejalan Kaki, b). Lapak Tunggu, c) Lampu Penerangan.

\section{Kriteria Pejalan Kaki Di Jembatan Penyeberangan}

Volume pejalan kaki yang dimaksudkan disini adalah jumlah pejalan kaki yang menyeberang, dengan menggunakan fasilitas jembatan penyeberangan dan tidak lewat fasilitas penyeberangan (melintas ruas jalan langsung).

1. Kriteria Tingkat Pemanfaatan Jembatan Penyeberangan

Penilaian tingkat pemanfaatan jembatan penyeberangan oleh pejalan kaki didasarkan pada hasil penelitian Hankin B.D., Wright R.A, 1958, dalam Mashuri, at all (2012) seperti yang disajikan pada tabel 1 dibawah ini. 
Tabel 1. Kriteria Tingkat Pemanfaatan Jembatan Penyeberangan

\begin{tabular}{lcc|}
\hline \multirow{2}{*}{ Tingkat Pemanfaatan } & \multicolumn{2}{c|}{ Persentase Jumlah Pejalan Kaki yang Menyeberang } \\
\cline { 2 - 3 } & $\begin{array}{c}\text { \% Memakai Jembatan } \\
\text { Penyeberang }\end{array}$ & $\begin{array}{c}\text { \% Tidak Memakai } \\
\text { Jembatan Penyeberang }\end{array}$ \\
\hline Sangat Tidak Bermanfaat & $0-20$ & $100-80$ \\
Tidak Bermanfaat & $21-40$ & $79-60$ \\
Cukup Bermanfaat & $41-60$ & $59-40$ \\
Bermanfaat & $61-80$ & $39-20$ \\
Sangat Bermanfaat & $81-100$ & $19-0$ \\
\hline
\end{tabular}

Sumber: Hankin B.D., Wright R.A., 1958 dalam Mashuri et al, 2012.

Untuk mengetahui persentase tingkat pemanfaataan untuk jembatan penyeberangan dapat dirumuskan sebagai berikut :

Kriteria tingkat pemanfaatan $(\%)=\frac{\text { Volume penyeberang jalan }}{\text { Total volume penyeberang jalan }} \times 100 \%$

2. Kriteria Pemilihan Penyeberangan

Tabel 2. Rekomendasi pemilihan fasilitas penyeberangan sebidang

\begin{tabular}{cccc}
\hline $\mathbf{P V}^{2}$ & $\begin{array}{c}\text { P } \\
\text { (volume rata-rata } \\
\text { penyeberang } \\
\text { jalan) }\end{array}$ & $\begin{array}{c}\text { V } \\
\text { (volume total } \\
\text { kendaraan } 2 \\
\text { arah) }\end{array}$ & $\begin{array}{c}\text { Rekomendasi } \\
\text { Awal }\end{array}$ \\
\hline$>10^{8}$ & $50-1.100$ & $300-500$ & Zebra Cross (ZC) \\
$>2 \times 10^{8}$ & $50-1.100$ & $400-750$ & ZC dgn pelindung \\
$>10^{8}$ & $50-1.100$ & $>500$ & Pelikan (P) \\
$>10^{8}$ & $>1.100$ & $>500$ & Pelikan (P) \\
$>2 \times 10^{8}$ & $50-1.100$ & $>700$ & P dgn Pelindung \\
$>2 \times 10^{8}$ & $>1.100$ & $>400$ & P dgn Pelindung \\
\hline
\end{tabular}

Sumber : Dirjen Perhubungan Darat 1997

Tabel 3. Rekomendasi pemilihan fasilitas penyeberangan tidak sebidang

\begin{tabular}{|c|c|c|c|}
\hline $\mathbf{P V}^{2}$ & $\begin{array}{c}P \\
\text { (volume rata-rata } \\
\text { penyeberang } \\
\text { jalan) }\end{array}$ & $\begin{array}{c}\mathrm{V} \\
\text { (volume total } \\
\text { kendaraan } 2 \\
\text { arah) }\end{array}$ & Rekomendasi Awal \\
\hline$>5 \times 10^{8}$ & $100-1250$ & $2000-5000$ & Zebra Cross (ZC) \\
\hline$>10^{10}$ & $3500-7000$ & $400-750$ & $\begin{array}{l}\mathrm{ZC} \text { dgn lampu } \\
\text { pengatur }\end{array}$ \\
\hline$>5 \times 10^{9}$ & $100-1250$ & $>500$ & $\begin{array}{c}\text { Dgn lampu } \\
\text { pengatur/jembatan }\end{array}$ \\
\hline$>5 \times 10^{9}$ & $>1250$ & $>2000$ & $\begin{array}{c}\text { Dgn lampu } \\
\text { pengatur/jembatan }\end{array}$ \\
\hline$>10^{10}$ & $100-1250$ & $>7000$ & Jembatan \\
\hline$>10^{10}$ & $>1250$ & $>3500$ & Jembatan \\
\hline
\end{tabular}

Sumber : Departmental Advice Note TA/10/80 dalam Mashuri, Muh Ikbal, 2011

\section{METODOLOGI}

\section{Pengumpulan Data}

1. Penelitian ini dilakukan pada JPO di jalan Sultan Thaha.

2. Survei pejalan kaki dan kendaraan dilakukan sepanjang $133 \mathrm{~m}$ di sebelah timur dan $80 \mathrm{~m}$ di sebelah barat. 


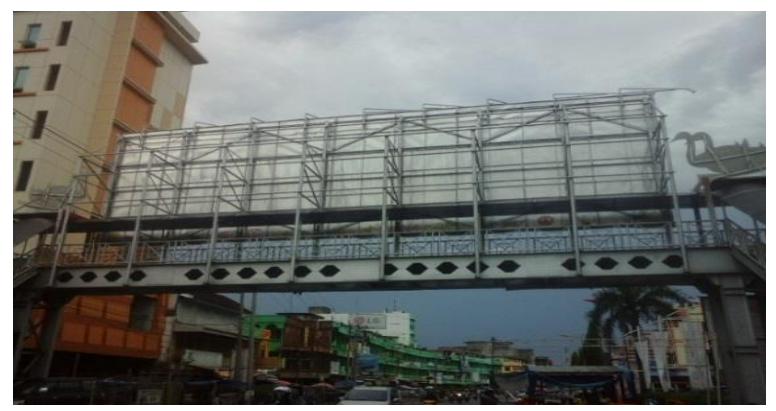

Sumber : dokumentasi hasil survey 2016

Gambar 1. Jembatan Penyeberangan Orang

\section{Volume Penyeberang Jalan}

Data penyeberang jalan di hitung pada jam 08.00-09.00 WIB, jam 11.0012.00 WIB, jam 12.00-13.00 WIB, dan jam 15.00-16.00 WIB, pengamatan di lakukan selama 3 (tiga) hari yaitu pada hari sabtu, minggu dan senin.

\section{Analisis Data}

Data yang sudah diperoleh di Lapangan dianalisis sebagai berikut :

1. Mengkonversikan jumlah kendaraan (sesuai jenis kendaraan) dalam satuan mobil penumpang (smp).

2. Menghitung volume kendaraan masing-masing hari atau sesi peninjauan $\mathrm{V}$ (smp/jam).

3. Menghitung volume peyeberang jalan masing-masing hari atau sesi peninjauan P (orang/jam).

4. Mengitung rata-rata volume kendaraan pada masing-masing jalan yang ditinjau $\mathrm{V}$ (smp/jam).

5. Menghitung rata-rata volume penyeberang jalan masing-masing jalan yang ditinjau P (orang/jam).

6. Menghitung dalam rumus $P V^{2}$.

7. Menentukan kelayakan jembatan penyeberangan orang yang dibangun.

\section{ANALISIS DAN PEMBAHASAN}

Analisis Tingkat Pemanfaatan Jembatan Penyeberangan

Hasil analisa data para pejalan kaki yang menyeberang jalan baik menggunakan JPO maupun tidak menggunakan JPO dalam menyeberang jalan pada daerah pusat perbelanjaan Mall WTC di Jalan Sultan Thaha Kota Jambi.

Tabel 4. Hasil analisis volume penyeberang jalan pada pertama. Hasil analisis volume penyeberang jalan (P)

\begin{tabular}{cccc} 
Waktu & \multicolumn{3}{c}{$($ Pejalan kaki/jam $)$} \\
\cline { 2 - 4 } & $\begin{array}{c}\text { Melewati jembatan } \\
\text { penyeberangan }\end{array}$ & $\begin{array}{c}\text { Melewati ruas jalan } \\
\text { raya }\end{array}$ & Total \\
\hline $08.00-09.00$ & 4 & 124 & 128 \\
$11.00-12.00$ & 24 & 315 & 339 \\
$12.00-13.00$ & 37 & 342 & 379 \\
$15.00-16.00$ & 43 & 411 & 454 \\
Total & 108 & 1192 & 1300 \\
Persentase & $8,31 \%$ & $91,69 \%$ & $100 \%$ \\
Kesimpulan & \multicolumn{3}{c}{ Sangat tidak bermanfaat } \\
\hline
\end{tabular}

Sumber : Hasil analisis, 2016

Kajian Azaz Manfaat Jembatan Penyeberangan Orang (JPO) di Jalan Sultan 
Jumlah pejalan kaki yang menyeberang pada hari pertama yang menggunakan jembatan penyeberangan sebesar 108 orang, sedangkan yang tidak menggunakan jembatan penyeberangan sebesar 1192 orang. Maka efektifitas dapat dihitung dengan formula :

Menganalisis tingkat pemanfaatan yang menggunakan jembatan penyeberangan.

Kriteria tingkat pemanfaatan $=\frac{108}{1300} \times 100 \%=\mathbf{8 , 3 1 \%}$

Menganalisis tingkat pemanfaatan yang tidak menggunakan jembatan penyeberangan.

Kriteria tingkat pemanfaatan $=\frac{1192}{1300} \times 100 \%=\mathbf{9 1 , 6 9 \%}$

Tabel 5. Hasil analisis volume penyeberang jalan pada hari kedua.

\begin{tabular}{cccc}
\hline & \multicolumn{3}{c}{$\begin{array}{c}\text { Hasil analisis volume penyeberang jalan (P) } \\
\text { (Pejalan kaki/jam) }\end{array}$} \\
\cline { 2 - 4 } Waktu & $\begin{array}{c}\text { Melewati jembatan } \\
\text { penyeberangan }\end{array}$ & $\begin{array}{c}\text { Melewati ruas jalan } \\
\text { raya }\end{array}$ & Total \\
\hline $08.00-09.00$ & 6 & 172 & 178 \\
$11.00-12.00$ & 32 & 458 & 490 \\
$12.00-13.00$ & 48 & 516 & 564 \\
$15.00-16.00$ & 36 & 351 & 387 \\
Total & 122 & 1497 & 1619 \\
Persentase & $7,54 \%$ & $92,46 \%$ & $100 \%$ \\
Kesimpulan & \multicolumn{3}{c}{ Sangat tidak bermanfaat } \\
\hline
\end{tabular}

Sumber : Hasil analisis, 2016

Jumlah pejalan kaki yang menyeberang menggunakan jembatan penyeberangan sebesar 122 orang, sedangkan yang tidak menggunakan jembatan penyeberangan sebesar 1497orang. Maka efektifitas dapat dihitung dengan formula analisis tingkat pemanfaatan yang menggunakan jembatan penyeberangan.

Kriteria tingkat pemanfaatan $=\frac{122}{1619} \times 100 \%=\mathbf{7 , 5 4 \%}$

Analisis tingkat pemanfaatan yang tidak menggunakan jembatan penyeberangan.

Kriteria tingkat pemanfaatan $=\frac{1497}{1619} \times 100 \%=\mathbf{9 2 , 4 6 \%}$

Tabel 6. Hasil analisis volume penyeberangan jalan pada hari ketiga.

\begin{tabular}{cccc}
\hline \multirow{2}{*}{ Waktu } & \multicolumn{3}{c}{$\begin{array}{c}\text { Hasil analisis volume penyeberang jalan (P) } \\
(\text { Pejalan kaki/jam) }\end{array}$} \\
\cline { 2 - 4 } & $\begin{array}{c}\text { Melewati jembatan } \\
\text { penyeberangan }\end{array}$ & $\begin{array}{c}\text { Melewati ruas jalan } \\
\text { raya }\end{array}$ & Total \\
\hline $08.00-09.00$ & 12 & 210 & 222 \\
$11.00-12.00$ & 23 & 284 & 307 \\
$12.00-13.00$ & 28 & 325 & 353 \\
$15.00-16.00$ & 7 & 266 & 273 \\
Total & 70 & 1085 & 1155 \\
Persentase & $6,06 \%$ & $93,94 \%$ & $100 \%$ \\
Kesimpulan & \multicolumn{3}{c}{ Sangat tidak bermanfaat } \\
\hline
\end{tabular}

Sumber : Hasil analisis, 2016

Jumlah pejalan kaki yang menyeberang yang menggunakan jembatan penyeberangan sebesar 70 orang, sedangkan yang tidak menggunakan jembatan

Kajian Azaz Manfaat Jembatan Penyeberangan Orang (JPO) di Jalan Sultan Thaha Kota Jambi 
penyeberangan sebesar 1085 orang. Maka efektifitas dapat dihitung dengan formula analisis tingkat pemanfaatan yang menggunakan jembatan penyeberangan.

Kriteria tingkat pemanfaatan $=\frac{70}{1155} \times 100 \%=\mathbf{6 , 0 6 \%}$

Analisis tingkat pemanfaatan yang tidak menggunakan jembatan penyeberangan.

Kriteria tingkat pemanfaatan $=\frac{1085}{1155} \times 100 \%=\mathbf{9 3 , 9 4 \%}$

Berdasarkan kriteria tingkat pemanfaatan jembatan penyeberangan pada tabel 1, analisis hasil survey dari hari pertama sampai hari ketiga sangat tidak bermanfaat yang berada di persentase $0-20 \%$, di karenakan banyak penyeberang yang melintas ruas jalan.

Maka total rata-rata tingkat pemanfaatan jembatan penyeberangan pada Tabel 4 sampai dengan Tabel 7 adalah sebesar 7,30\%. Sehingga Jembatan penyeberangan sangat tidak dimanfaatkan oleh para pejalan kaki untuk menyeberang jalan pada daerah perbelanjaan di Jalan Sultan Thaha Kota Jambi.

\section{Analisis Pemilihan Fasilitas Penyeberangan}

Volume lalu lintas dan volume pejalan kaki menyeberang yang menyeberang melalui jalan raya lansung dan yang menyeberang di jembatan.

Tabel 7. Volume Penyeberang Jalan dan Volume Kendaraan Pada Hari Pertama.

\begin{tabular}{cccc}
\hline Waktu & Volume Penyeberang $(\mathrm{P})$ & Volume Kendaraan $(\mathrm{V})$ & $\mathrm{PV}^{2}$ \\
\hline $08.00-09.00$ & 128 & 1760 & 225280 \\
\hline $11.00-12.00$ & 339 & 2500 & 847500 \\
\hline $12.00-13.00$ & 379 & 2787 & 1056273 \\
\hline $15.00-16.00$ & 454 & 3396 & 1541784 \\
\hline
\end{tabular}

Sumber : Hasil analisis, 2016

Kesesuaian fasilitas penyeberangan dengan persyaratan yang ada dan untuk merekomendasikan fasilitas yang sesuai dapat dihitung dari volume penyeberang jalan dan volume kendaraan tertinggi pada jam puncak yaitu:

$\mathrm{P}=(128+339+379+454) / 4=\mathbf{3 2 5 , 0 0}$ pejalan kaki/jam

$\mathrm{V}=(1760+2500+2787+3396) / 4=\mathbf{2 6 1 0 , 7 5}$ kend./jam

Jumlah rata-rata pejalan kaki pada jam sibuk $325,00<1250$ pejalan $\mathrm{kaki} /$ jam dan volume kendaraan 2610,75 $<5000$ kendaraan/jam, P. $\mathrm{V}^{2}>5 \times 10^{8}$.

Tabel 8. Volume Penyeberang Jalan dan Volume Kendaraan Pada Hari Kedua.

\begin{tabular}{cccc}
\hline Waktu & Volume Penyeberang $(\mathrm{P})$ & Volume Kendaraan $(\mathrm{V})$ & $\mathrm{PV}^{2}$ \\
\hline $08.00-09.00$ & 178 & 2081 & 370418 \\
$11.00-12.00$ & 490 & 2914 & 1427860 \\
$12.00-13.00$ & 564 & 3213 & 1812132 \\
$15.00-16.00$ & 387 & 3435 & 1329345 \\
\hline
\end{tabular}

Sumber : Hasil analisis, 2016

Kesesuaian fasilitas penyeberangan dengan persyaratan yang ada dan untuk merekomendasikan fasilitas yang sesuai dapat dihitung dari volume penyeberang jalan dan volume kendaraan tertinggi pada jam puncak yaitu:

$\mathrm{P}=(178+490+564+387) / 4=\mathbf{4 0 4 , 7 5}$ pejalan $\mathrm{kaki} / \mathrm{jam}$

$\mathrm{V}=(2081+2914+3213+3435) / 4=\mathbf{2 9 1 0 , 7 5}$ kend./jam

Kajian Azaz Manfaat Jembatan Penyeberangan Orang (JPO) di Jalan Sultan

Thaha Kota Jambi 
Jumlah rata-rata pejalan kaki pada jam sibuk 404,75 < 1250 pejalan kaki/jam dan volume kendaraan 2910,75 $<5000$ kendaraan/jam, P. $\mathrm{V}^{2}>5$ x $10^{8}$.

Tabel 9. Volume Penyeberang Jalan dan Volume Kendaraan Pada Hari Ketiga

\begin{tabular}{cccc}
\hline Waktu & Volume Penyeberang $(\mathrm{P})$ & Volume Kendaraan $(\mathrm{V})$ & $\mathrm{PV}^{2}$ \\
\hline $08.00-09.00$ & 222 & 1425 & 316350 \\
$11.00-12.00$ & 307 & 2006 & 615842 \\
$12.00-13.00$ & 353 & 2150 & 758950 \\
$15.00-16.00$ & 273 & 2358 & 643734 \\
\hline
\end{tabular}

Sumber : Hasil analisis, 2016

Untuk menilai kesesuaian fasilitas penyeberangan dengan persyaratan yang ada dan untuk merekomendasikan fasilitas yang sesuai dapat dihitung dari volume penyeberang jalan dan volume kendaraan tertinggi pada jam puncak yaitu seperti perhitungan di bawah ini :

$\mathrm{P}=(222+307+353+273) / 4=\mathbf{2 8 8 , 7 5}$ pejalan $\mathrm{kaki} / \mathrm{jam}$

$\mathrm{V}=(1425+2006+2150+2358) / 4=\mathbf{1 9 8 4 , 7 5}$ kend./jam

Jumlah rata-rata pejalan kaki pada jam sibuk 288,75<1250 pejalan kaki/jam dan volume kendaraan 1984,75 < 5000 kendaraan/jam, P.V ${ }^{2}>5$ x $10^{8}$. Berdasarkan perhitungan dari ketiga hari tabel 7,8 dan 9 maka pemilihan fasilitas penyeberangan sesuai pada tabel 3, dapat ditarik kesimpulan fasilitas yang direkomendasikan adalah fasilitas penyeberangan Zebra CroSs (ZC).

\section{Analisis Kapasitas Jalan}

Dilihat dari kondisi ruas jalan yang menjadi lokasi tempat menyeberang, maka kapasitas ruas jalan dan derajat kejenuhan dapat dihitung dengan menggunakan MKJI 1997, di bawah ini :

Tabel 10. Kapasitas Jalan di Lokasi Pejalan Kaki Yang Menyeberang Jalan

\begin{tabular}{lcc}
\hline \multicolumn{2}{c}{ Penyesuaian Kapasitas } & Faktor \\
\hline Kapasitas Dasar (Co) & Jalan Satu Arah (lima lajur) & $3 \times 1.650$ \\
Lebar Jalur (FCw) & $3.5 \mathrm{~m}$ & 1 \\
Pemisah Arah (FCsp) & $70-30 \%$ & 0,88 \\
Hambatan Samping (FCsf) & Lebar bahu < 1 M & 0,95 \\
Penyesuaian Kota (FCcs) & $0.5-1$ Juta penduduk & 0.94 \\
\multicolumn{2}{c}{ Kapasitas (C) = Co. FCw. FCsp. FCsf. FCcs (smp/jam) } & $\mathbf{3 8 8 9 . 9 1}$ \\
\hline
\end{tabular}

Sumber : Hasil olahan data, 2016

\section{Analisis Derajat Kejenuhan}

Kepadatan lalu lintas pada ruas jalan Sultan Thaha dapat dilihat melalui derajat kejenuhan pada lokasi tersebut. Dari hasil perhitungan diperoleh nilai derajat kejenuhan (DS) jalan seperti di bawah ini :

Tabel 11. Derajat kejenuhan jalan Sultan Thaha Hari Pertama.

\begin{tabular}{ccccc}
\hline No & Waktu & $\begin{array}{c}\text { Volume Kendaraan } \\
\text { (Q) smp/jam }\end{array}$ & $\begin{array}{c}\text { Kapasitas } \\
(\mathrm{C}) \text { smp/jam }\end{array}$ & Derajat Kejenuhan (DS) \\
\hline 1 & $08.00-09.00$ & 1046,90 & 3889.91 & 0,27 \\
2 & $11.00-12.00$ & 1633,00 & 3889.91 & 0,42 \\
3 & $12.00-13.00$ & 1808,70 & 3889.91 & 0,46 \\
4 & $15.00-16.00$ & 2196,60 & 3889.91 & 0,56 \\
\multicolumn{5}{c}{ Rata - rata } \\
\hline
\end{tabular}

Sumber : Hasil analisis, 2016 
Tabel 12. Derajat kejenuhan jalan Sultan Thaha pada hari Kedua

\begin{tabular}{ccccc}
\hline No & Waktu & $\begin{array}{c}\text { Volume Kendaraan } \\
\text { (Q) smp/jam }\end{array}$ & $\begin{array}{c}\text { Kapasitas } \\
\text { (C) smp/jam }\end{array}$ & $\begin{array}{c}\text { Derajat Kejenuhan } \\
\text { (DS) }\end{array}$ \\
\hline 1 & $08.00-09.00$ & 1207,40 & 3889.91 & 0,31 \\
2 & $11.00-12.00$ & 1828,90 & 3889.91 & 0,47 \\
3 & $12.00-13.00$ & 2026,20 & 3889.91 & 0,52 \\
4 & $15.00-16.00$ & 2226,30 & 3889.91 & 0,57 \\
\multicolumn{5}{c}{ Rata - rata } \\
\hline
\end{tabular}

Sumber : Hasil analisis, 2016

Tabel 13. Derajat kejenuhan jalan Sultan Thaha pada Hari Ketiga

\begin{tabular}{ccccc}
\hline No & Waktu & $\begin{array}{c}\text { Volume Kendaraan } \\
(\mathrm{Q}) \text { smp/jam }\end{array}$ & $\begin{array}{c}\text { Kapasitas } \\
(\mathrm{C}) \text { smp/jam }\end{array}$ & Derajat Kejenuhan (DS) \\
\hline 1 & $08.00-09.00$ & 856,50 & 3889.91 & 0,22 \\
2 & $11.00-12.00$ & 1332,20 & 3889.91 & 0,34 \\
3 & $12.00-13.00$ & 1403,60 & 3889.91 & 0,36 \\
4 & $15.00-16.00$ & 1517,40 & 3889.91 & 0,39 \\
\multicolumn{5}{c}{ Rata - rata } \\
\hline
\end{tabular}

Sumber : Hasil analisis, 2016

Maka untuk melihat kepadatan lalu lintas dari ketiga hari pengamatan dapat di hitung dengan formula di bawah ini: $\mathrm{DS}=\mathrm{Q} / \mathrm{C}$.

Nilai DS pada tabel 11,12,13 pada lokasi ruas jalan dibawah jembatan penyeberang masih di bawah $\mathbf{0 , 7 5}$, dinilai lalu lintas belum terlalu padat sehingga belum perlu menggunakan fasilitas jembatan penyeberangan.

\section{Analisis Pertumbuhan Lalu Lintas}

Survey lapangan yang dilakukan di lokasi dapat diketahui besarnya volume lalu lintas untuk menganalisis kapasitas ruas jalan tersebut. LHRo yang diperoleh dari perhitungan diambil nilai volume kendaraan terbesar (Q) yaitu 2226,30 smp/hari dan nilai tingkat pertumbuhan lalu lintas (i) diambil dari hasil survey oleh Dinas Perhubungan Provinsi Jambi pada tahun 2015 yaitu 3.3\% pertahun dan nilai $(n)$ merupakan umur perkiraan untuk mencapai kepadatan kendaraan yang di inginkan yaitu 0,75 .

LHRT $=2226,3 \times(1+0,033)^{8,3}=\mathbf{2 9 1 4 . 8 5} \mathrm{smp} / \mathrm{jam}$

$\mathrm{DS}_{2024}=2914.85 / 3889.91=\mathbf{0 , 7 5}$

Dari hasil analisis lalu lintas harian rata-rata (LHRT), maka dapat diperkirakan pertumbuhan lalu lintas pada 8 tahun 3 bulan yang akan guna mencapai kepadatan lalu lintas harian rata-rata (LHRT) sebesar $2914.85 \mathrm{smp} / \mathrm{jam}$ dan didapat dengan nilai kepadatan kendaraan sebesar 0,75. Maka jembatan penyeberangan orang tersebut selayaknya dibangun lebih kurang pada tahun 2024.

Analisis Orang yang Menyeberang

Tabel 14. Data Penduduk Kota Jambi

\begin{tabular}{ccc}
\hline Tahun & $\begin{array}{c}\text { Jumlah Penduduk } \\
\text { Laki-laki dan Perempuan }\end{array}$ & $\begin{array}{c}\text { Persentase Pertumbuhan } \\
\text { Penduduk Pertahun }\end{array}$ \\
\hline 2010 & 534.500 Orang & $13.64 \%$ \\
2011 & 543.193 Orang & $13.87 \%$ \\
2012 & 551.714 Orang & $14.08 \%$
\end{tabular}

Kajian Azaz Manfaat Jembatan Penyeberangan Orang (JPO) di Jalan Sultan Thaha Kota Jambi 


\begin{tabular}{lll}
\hline 2013 & 560.188 Orang & $14.30 \%$ \\
2014 & 568.062 Orang & $14.50 \%$ \\
2015 & 576.067 Orang & $14.71 \%$ \\
2016 & 583.487 Orang & $14.90 \%$ \\
\hline
\end{tabular}

Sumber : Badan Pusat Statistik Provinsi Jambi, 2016

Pertumbuhan penduduk di Kota Jambi yaitu 14.90\%. Dari data persentase pertumbuhan penduduk di dapat perkiraan jumlah penyeberang yang akan menyeberang di jembatan pada 8 tahun 3 bulan kedepan. Jumlah penyeberang yang maksimum pada saat sekarang yaitu 564 orang/jam, dari data tersebut maka di dapat jumlah penyeberang pada tahun 2024 yaitu 1.786 orang/jam.

\section{SIMPULAN}

1. Hasil analisis didapatkan tingkat pemanfaatan sebesar $8,31 \%$. Dengan tingkat pemanfaatan jembatan penyeberangan $0-20 \%$, maka jembatan penyeberangan tersebut sangat tidak bermanfaat atau belum bermanfaat secara optimal untuk saat sekarang.

2. Hasil analisis volume penyeberangan jalan $(\mathrm{P})$ dan volume kendaraan (V) pada lokasi diperoleh hasil penyeberangan di Jalan Sultan Thaha adalah 325,00 < 1250 pejalan kaki/jam dan volume kendaraan 2610,75 $<5000$ kendaraan/jam dan $\mathrm{PxV}^{2}>5 \times 10^{8}$, maka fasilitas yang memenuhi kriteria saat sekarang adalah Zebra Cross (ZC), sehingga belum memenuhi kriteria pembuatan jembatan penyeberangan orang.

3. Penggunaan jembatan penyeberangan ditinjau dari derajat kejenuhan (DS) pada ruas jalan pada jam sibuk dan hri libur jam 15.00-16.00 $=0,57<0,75$, dinilai lalu lintas belum terlalu padat.

4. Perhitungan lalu lintas harian rata-rata (LHRT) pada tahun 2024 diperoleh $2914.85 \mathrm{smp} / \mathrm{jam}$ dengan nilai kepadatan kendaraan sebesar 0,75 , maka dapat diperkirakan pada 8 tahun 3 bulan kedepan jembatan penyeberangan orang baru termanfaatkan.

\section{Saran}

1. Lakukan pemasangan pagar dimedian jalan sepanjang $133 \mathrm{~m}$ di sebelah timur dan $80 \mathrm{~m}$ di sebelah barat, dan dilakukan perawatan pada fisik jembatan agar selalu dalam kondisi baik.

2. Jembatan penyeberangan tetap perlu dioperasikan mengingat pentingnya factor keamanan dan keselamatan bagi pejalan kaki dan lalu lintas, maka perlu adanya rekayasa agar masyarakat pejalan kaki yang akan menyeberang tertarik untuk melintas melalui jembatan.

\section{DAFTAR PUSTAKA}

Badan Pusat Statistik Provinsi Jambi, 2016

Departemen Pekerjaan Umum Direktorat Jenderal Bina Marga. 1997. Manual Kapasitas Jalan Indonesia (MKJI). Jakarta: Republik Indonesia.

Departemen Dirjen Perhubungan Darat, 1997, Perekayasaan Fasilitas Pejalan Kaki di Wilayah Kota. Jakarta. Republik Indonesia

Departemen Pekerjaan Umum Direktorat Jenderal Bina Marga. 1995. Tata Cara

Perencanaan Fasilitas Pejalan Kaki di Kawasan Perkotaan. Jakarta: Bina Teknik 
Departemen Pekerjaan Umum Direktorat Jenderal Bina Marga. 1999. Pedoman Perencanaan Jalur Pejalan Kaki pada Jalan Umum. Jakarta: Republik Indonesia.

Dinas Perhubungan Provinsi Jambi. 2015. Survey pertumbuhan lalu-linta tahun 2015.

Mashuri dan Muh. Ikbal. 2011. Studi Karakteristik Pejalan Kaki dan Pemilihan Jenis Fasilitas Penyeberangan Pejalan Kaki Di Kota Palu. Kota Palu: Universitas Tadulako.

Mashuri dan Sigit Widodo, 2012. Tingkat Pemanfaatan dan Faktor-faktor Yang Mempengaruhi Pemakaiaan Jembatan Penyeberangan Orang di Depan Mall Tatura Kota Palu. Kota Palu: Universitas Tadulako.

Peraturan Menteri Perhubungan. 1993. Tentang Prasarana dan Lalu Lintas Jalan. Jakarta: Republik Indonesia.

Peraturan Menteri Perhubungan. 2006. Manajemen Dan Rekayasa Lalu Lintas Di Jalan. Jakarta: Republik Indonesia.

Yamali FR, 2017, Pengaruh Kompensasi dan Kompetensi Terhadap Komitmen Organisasi Serta Implikasinya pada Kinerja Tenaga Ahli Perusahaan Jasa Konstruksi di Provinsi Jambi, Jambi, Jurnal of Economics and Business, ISSN 2597-8829 Universitas Batanghari. 